Indonesian Journal of Physics and Nuclear Applications

Volume 1, Number 1, February 2016, p. 54-62

ISSN 2549-046X, C FSM UKSW Publication

\title{
Optimization of Neutron Collimator in The Thermal Column of Kartini Research Reactor for in vitro and in vivo Trials Facility of Boron Neutron Capture Therapy using MCNP-X Simulator
}

\author{
Ranti Warfi $^{1}$, Andang Widi Harto ${ }^{1}$, Yohannes Sardjono ${ }^{2}$, Widarto \\ ${ }^{1}$ Physics Engineering Department, Gadjah Mada University \\ Jln. Grafika 2 Yogyakarta 55281 Indonesia \\ ranti.warfi@mail.ugm.ac.id, andang@ugm.ac.id \\ ${ }^{2}$ Center for Accelerator Science and Technology, National Nuclear Energy Agency \\ Jln. Babarsari no 21 Kotak Pos 6101 ykbb Yogyakarta, 55281, Indonesia \\ sardjono.batan@gmail.com
}

Received: 10 Juni 2015, Revised: 28 October 2015, Accepted: January 2016

\begin{abstract}
The optimization of thermal column collimator has been studied which resulted epithermal neutron beam for in vivo and in vitro trials of Boron Neutron Capture Therapy (BNCT) at Kartini Research Reactor of $100 \mathrm{~kW}$ by means of Monte Carlo N-Particle Extended (MCNP-X) codes. The design criteria were based on recommendation from the International Atomic Energy Agency (IAEA). MCNP-X calculations indicated by using $5 \mathrm{~cm}$ thickness of $\mathrm{Ni}$ as collimator wall, $30 \mathrm{~cm}$ thickness of $\mathrm{Al}$ as moderator, $20 \mathrm{~cm}$ thickness of $60 \mathrm{Ni}$ as filter, $2 \mathrm{~cm}$ thickness of $\mathrm{Bi}$ as $\gamma$-ray shielding, $3 \mathrm{~cm}$ thickness of 6 $\mathrm{Li} 2 \mathrm{CO} 3$-polyethylene as beam delimiter, and for in vivo in vitro trials purpose, aperture was designed $8 \mathrm{~cm}$ radius size, an epitermal neutron beam with an intensity $1.13 \mathrm{E}+09 \mathrm{n} . \mathrm{cm}-2 . \mathrm{s}-1$, fast neutron and $\gamma$-doses per epithermal neutron of 1.76E-13 Gy.cm2.n-1 and 1.45E-13Gy.cm2.n-1,minimum thermal neutron per epithermal neutron ratio of 0.008 , and maximum directionality of 0.73 , respectively could be produced. The results have passed all the IAEA's criteria.
\end{abstract}

Keywords optimization; collimator; BNCT; MCNP-X; in vivo in virtro trials; IAEA's criteria

\section{INTRODUCTION}

Cancer is one of leading cause of death worldwide, encounted for $8.2 \%$ of death cause by cancer in 2012 (RI, 2015). About 70\% all of deaths occurred in low middle, in Indonesia about 136 males and 109 females dead of cancer for every 100.000 cases in 2008. Deaths from cancer worldwide projected to exceed over 13.1 million in 2030 (World Health Organization, 2015).

The most well-known radiation types applied to radiotherapy are gamma ray $(\gamma)$ and $\mathrm{X}$-ray, this type of therapy used high energy doses that cause ionization around normal tissue, besides those kind of beam have rarely effective since they were found to have relatively low Linear Energy Transfer (LET) $\left(53 \mathrm{keV} . \mu \mathrm{m}^{-1}\right.$ or less) (Nakagawa, 2012).
Boron Neutron Capture Therapy (BNCT) is a therapy for cancer which uses neutron as radiation source. An ideal radiation source for cancer therapy could destroy cance cells effectively without dangerous effect for normal tissue around. In BNCT, 10B and its carrier drug are administered to the patient. This carrier will take these compounds to the location of the tumour cells, where $10 \mathrm{~B}$ is supposed to be accumulated. On the next step, the tumour area is to be irradiated by neutron beam. Then, $10 \mathrm{~B}$ in the tumour cells captures the thermal neutron, resulting in a prompt nuclear reaction $10 \mathrm{~B}(\mathrm{n}, \alpha) 7 \mathrm{Li}$. The particles coming from the neutron capture by $10 \mathrm{~B}$ have two possible energies that are $\alpha$ dan nucleus ${ }^{7} \mathrm{Li}$. Both of $\alpha$ dan 7Li have high LET ( $\geq 175 \mathrm{keV} . \mu \mathrm{m}-1)$ and short path lengths (arround 4.5-10 $\mu \mathrm{m}$ ), hence 
the energy deposition is locally limited around the tumour cells (K W Burn, 2006). BNCT treatment process illustrated in figure 1.

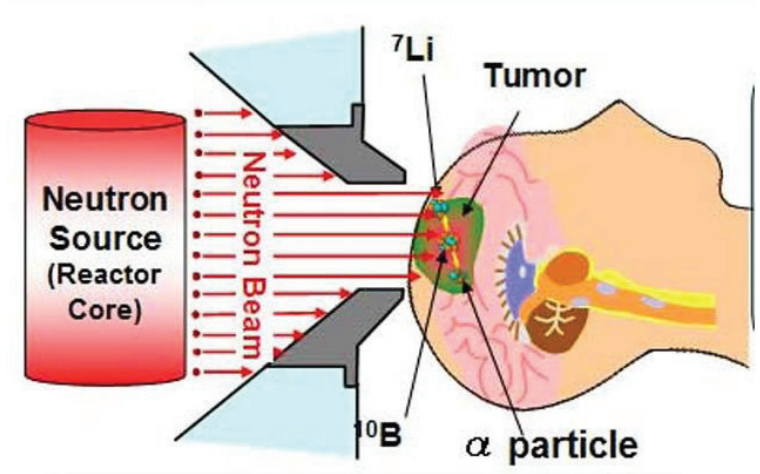

Figure 1. BNCT treatment process (Tribe, n.d.)

In Indonesia TRIGA MARK-II reactor Yogyakarta are planned to be added with a facility for BNCT purpose, TRIGA MARK-II is a research reactor type in Yogyakarta well known as Kartini research reactor is going to be built for advanced study which uses for in vivo and in vitro trials. For BNCT facility purpose this reactor desire to be operated at $100 \mathrm{~kW}$ thermal power, mean energy are emmited from fission reaction from reactor cannot be used directly in BNCT, it is necessary to moderate them to epithermal energy range about 0.4 $\mathrm{eV}$ to $10 \mathrm{KeV}$ (K W Burn1, 2006), For this purpose, neutrons must pass through a system that contains different materials. Such a system is called Beam Shaping Assembly (BSA) (Fatemeh S. Rasouli, 2012), due to the tendency of epithermal neutron beam usage for BNCT, an optimization of collimator is needed, designing objective is to deliver an epithermal neutron beam within a reasonable treatment time and to produce the desired thermal neutrons at tumour depth with minimal other radiations present.

From the 1950 up to 1994, thermal neutron beams were used in BNCT. However, the dose distribution of the thermal neutrons was poor. Epithermal neutrons were first utilised in USA in 1994 (MITR-II and BMRR) (SEPPÄLÄ,
2002). The recommended epithermal neutron flux based on IAEA criteria is $1 \mathrm{E}+10^{9}$ n.cm2.s-1, Beam quality is determined by free beam parameters as follows,

\section{Fast neutron component}

In BNCT the energy range for fast neutrons is taken as $>10 \mathrm{keV}$. Fast neutrons, which accompany the incident beam, have a number of undesirable characteristics such as free radicals production. Therefore, it is one of the main objectives of BNCT beam design to reduce the fast neutron component. In existing facilities, the range of dose from this component is from 2.5 to $13 \mathrm{x}$ 10-13 Gy.cm 2 per epithermal neutron, meanwhile the target number should be 2 x 10-13 Gy.cm2 per epithermal neutron (IAEA, 2001).

\section{Gamma ray component}

It is desirable to remove $\gamma$-ray radiation from the beam. A target number for this should be 2 x 10-13 Gy.cm2per epithermal neutron. The range in existing facilities is from 1 to 13 x 10-13 Gy.cm2 per epithermal neutron (IAEA, 2001).

\section{Ratio between thermal and epithermal flux}

To reduce damage to the scalp, thermal neutrons in the incident beam should be minimized. A target number for the ratio of thermal flux to epithermal flux should be 0.05 (IAEA, 2001).

\section{Ratio between total neutron current and total neutron flux}

This ratio provides a measure of the fraction of neutrons that are moving in the forward beam direction. A target number for this ratio should be greater than 0.7 (IAEA, 2001).

The aim to produce ideal neutron beam for BNCT, thus, optimization of collimator in 
order to fulfill IAEA beam criteria materials selection and the geometry optimizing is needed. Collimator common major component are; collimator wall, moderator, gamma ray shielding, neutron filter, and aperture.

\section{MATERIALS AND METHODS \\ Kartini Research Reactor Modelling}

Kartini Research Reactor is a TRIGA MARK-II research reactor type. It has a maximum thermal power of $250 \mathrm{~kW}$, the desired thermal power for this study was 100 $\mathrm{kW}$. According to the Safety Analysis Report (SAR), for gaining $100 \mathrm{~kW}$ of thermal power the control rods needed to be arranged in different axial positions. C5 control rod was dragged to $100 \%$, C9 to $65 \%$ and $\mathrm{E} 1$ to $55 \%$ of the active core height.

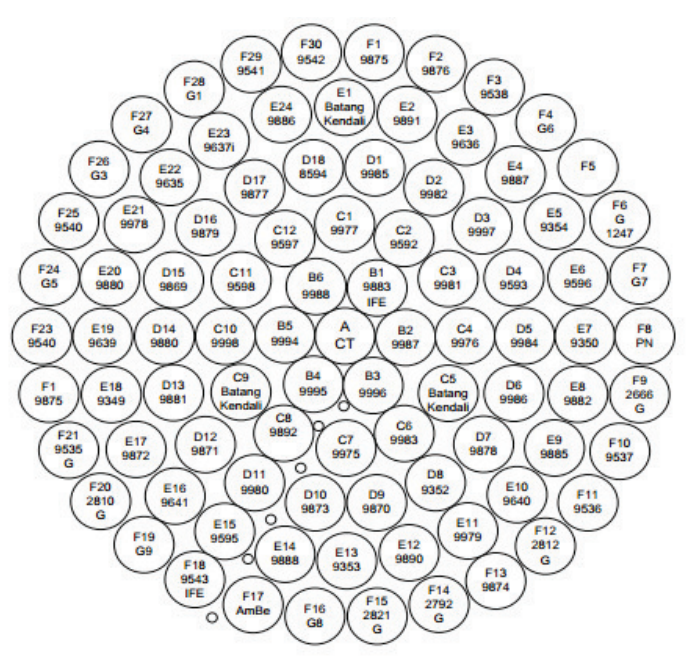

Figure 2. Kartini core reactor konfiguration (Sofia Mubarika, 2006)

Kartini Research Reactor specifications are documented in the SafetyAnalysis Report (SAR) of the reactor. It was needed to make a model of the reactor since it would be used as the neutrons source. In this case the fuel component assumed as new. By using these information, Kartini Research Reactor was modelled.

\section{Simulator}

MCNP-X was using as simulator to this research study. An MCNP input file is divided into 3 main blocks (which are known as cards) so called cell cards, surface cards, and data cards. The first two cards correspond to the geometry definition, while the data cards contain all the information related to the specification of the particle source, the definition of the materials, and the tallies.

Table 1. MCNP Tally Code (Lucas, 2010)

\begin{tabular}{|c|c|c|c|}
\hline Tally & $\begin{array}{l}\text { Particle } \\
\text { Mode }\end{array}$ & Description & Units \\
\hline $\mathrm{F} 1$ & $: \mathrm{N},: \mathrm{P}, \mathrm{E}$ & $\begin{array}{l}\text { Current integrated } \\
\text { over a surface }\end{array}$ & particles \\
\hline $\mathrm{F} 2$ & $: N,: P,: E$ & $\begin{array}{l}\text { Flux average over a } \\
\text { surface }\end{array}$ & particles $/ \mathrm{cm}^{2}$ \\
\hline $\mathrm{F} 4$ & $: N,: P,: E$ & $\begin{array}{l}\text { Flux average over } \\
\text { a cell }\end{array}$ & particles $/ \mathrm{cm}^{2}$ \\
\hline F5a & $: N,: P$ & $\begin{array}{l}\text { Flux at a point or } \\
\text { ring detector }\end{array}$ & particles $/ \mathrm{cm}^{2}$ \\
\hline F6 & $\begin{array}{l}: \mathrm{N},: \mathrm{P} \\
: \mathrm{N}, \mathrm{P}\end{array}$ & $\begin{array}{l}\text { Energy deposition } \\
\text { averaged over a cell }\end{array}$ & $\mathrm{MeV} / \mathrm{g}$ \\
\hline F7 & :N & $\begin{array}{l}\text { Fission energy } \\
\text { deposition averaged } \\
\text { over a cell }\end{array}$ & $\mathrm{MeV} / \mathrm{g}$ \\
\hline F8 & $\begin{array}{l}: \mathrm{N},: \mathrm{P},: \mathrm{E}, \\
\quad: \mathrm{P}, \mathrm{E}\end{array}$ & $\begin{array}{l}\text { Energy distribution } \\
\text { of pulses created in } \\
\text { a detector by radia- } \\
\text { tion }\end{array}$ & Pulses \\
\hline
\end{tabular}

$\mathrm{N}, \mathrm{P}$, and $\mathrm{E}$ are symbol for neutron, photon, and electron. Tally are selected based on component from dose calculation which are flux that pass through cell for neutron, gamma ray and electron, The tallies exploited for this work are F4: $\mathrm{N}$ for the calculation of neutron flux and dose rate averaged over a cell, F4:P for the calculation of photon dose rate averaged over a cell, and also F1:N for the calculation of neutron current integrated over a surface. F4 can be replaced, indeed, by F2, but it leads to a more complex code since we have to trim the surface and use the desired one. F4 tally was used for 3 aims. Meanwhile, in fact, in MCNP each tally can only be used for one aim. In 
other hand, having two F4: $\mathrm{N}$ for flux and dose calculation, and an F4:P in the same input file is not allowed. One needs to put one or two digits of additional number between $F$ and $n$ (the tally number) to make a difference for each tally. In this study, for instance, F4: $\mathrm{N}$ was used for neutron flux calculation, F14:N for fast neutron dose rate calculation, and F24:P for photon dose rate calculation

Normalization was clearly needed since the output unit from each MCNP tally did not match the unit used by the IAEA. First of all, fission rate needed for generating $100 \mathrm{~kW}$ thermal power was calculated as follows,

$$
\begin{aligned}
& \left(10^{5} \mathrm{~W}\right)\left(\frac{1 \mathrm{~J} / \mathrm{s}}{\mathrm{W}}\right)\left(\frac{1 \mathrm{MeV}}{1.602 \times 10^{-13} \mathrm{j}}\right)\left(\frac{1 \text { fission }}{200 \mathrm{MeV}}\right) \\
& =3.121 \times 10^{15} \text { fission } / \mathrm{s}
\end{aligned}
$$

Therefore, to produce $100 \mathrm{~kW}$ of thermal power, one needs $3.121 \times 10^{15}$ fissions per second. By using this fission rate, normalization factor for each tally were calculated as follows,

Flux and dose rate of neutron ( F4: $\mathrm{N}$ dan F14:N)

For average 2.42 per fission rate, normalization factor as follows,

$$
\begin{aligned}
& \left(3.121 \times 10^{15} \frac{\text { fission }}{s}\right)\left(\frac{2.42 \text { neutron }}{\text { fission }}\right) \\
& =7.553 \times 10^{15} \text { neutron } / \mathrm{s}
\end{aligned}
$$

Gamma dose rate ( F24:P)

For $1 \gamma$ rate per fission, normalization factor as follows,

$$
\left(3.121 \times 10^{15} \frac{\text { fission }}{s}\right)\left(\frac{1 \gamma}{\text { fission }}\right)=
$$

$$
3.121 \times 10^{15} \mathrm{r} / \mathrm{s}
$$

Neutron current ( F1:N )

For average 2.42 per fission rate, normalization factor as follows,

$$
\left(3.121 \times 10^{15} \frac{\text { fission }}{s}\right)\left(\frac{2.42 \text { neutron }}{\text { fission }}\right)=
$$

\section{$7.553 \times 10^{15}$ neutron $/ \mathrm{s}$}

It needs to be divided with the area which is prependicular to the neutron current. In this study, the multiplication factor for F1:N tally was varied due to its dependence on the size of collimator aperture. The maximum aperture diameter used was $16 \mathrm{~cm}$, for $16 \mathrm{~cm}$ aperture diameter, the normalization factor for $\mathrm{F} 1 \mathrm{~N}$ was,

$$
\frac{7.553 \times 10^{15} \text { neutron } / \mathrm{s}}{\pi(8 \mathrm{~cm})^{2}}=3.698 \times \frac{10^{13} \mathrm{n}}{\mathrm{cm}^{2} \cdot \mathrm{s}}
$$

Energy classifications for neutrons should be included in the input file for flux calculation, so each of thermal, epithermal, and fast neutron fluxes appeared in the output file, as follows

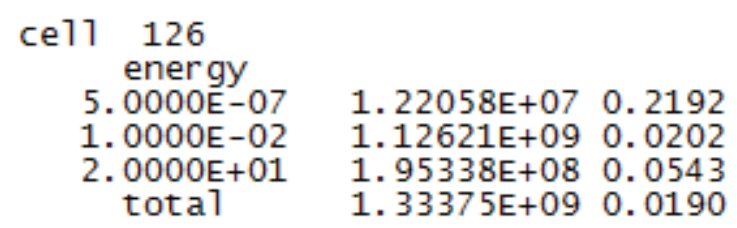

Figure 4.Simulation Result Output of MCNP

Related to the calculation of the dose based on the energy released by the radiation beam of neutrons and gamma photons of the material, the reference used is the table Kerma coefficients issued in Dosimetry system 2002(DS02) dari ICRU Report 63. Because the lower limit of the fast neutron energy is $10-2 \mathrm{MeV}$, the coefficient used Kerma is the energy above that value, while for gamma using Kerma coefficient for all energy ranges. Tally comment in MCNP 
was DEn and DFN. DEn is a card representing energy radiation beam while the DFN is Kerma coefficient correlated with DEn.

Besides, in the calculation of neutron flux required limits for the classification of energy neutron flux so that it can be distinguished for thermal neutrons, epithermal neutrons and fast neutrons. In MCNP, we can enter the upper limits of energy neutrons through En cards are separated by spaces, as MCNP calculate neutron flux below the limit. For this research limit of $5 \times 10-7,10-2$ and $20 \mathrm{MeV}$ was taken. It means that the thermal neutron are below $5 \mathrm{x}$ 10-7 MeV, epithermal neutrons are at $5 \times 10-7$ $<\mathrm{E}<10-2 \mathrm{MeV}$, and fast neutrons in the range $10-2<\mathrm{E}<20 \mathrm{MeV}$.

\section{a. Optimization of collimator}

Configuration of former collimator design component are,

1. $5 \mathrm{~cm} \mathrm{Ni-nat} \mathrm{as} \mathrm{collimator} \mathrm{wall.}$

2. $60 \mathrm{~cm} \mathrm{Al}$ as moderator.

3. $15 \mathrm{~cm} 60 \mathrm{Ni}$ as thermal and fast neutron filter.

4. $2 \mathrm{~cm} \mathrm{Bi}$ as gamma shielding

5. $3 \mathrm{~cm}$ 6Li2CO3-polyethylene

Output beam as follows,

Table 2. Colimator Design's Beam Parameter Before

\begin{tabular}{|c|c|}
\hline \multicolumn{2}{|c|}{ Optimization } \\
\hline$\Phi_{\text {epi }}($ n.cm-2.s-1) & $7.57 \mathrm{E}+08$ \\
\hline Ďf/ $\Phi_{\text {epi }}\left(G y \cdot \mathbf{c m}^{2} \cdot n^{-1}\right)$ & $1.76 \mathrm{E}-13$ \\
\hline Ď $\gamma / \Phi_{\text {epi }}\left(G y \cdot \mathbf{c m}^{2} \cdot \mathbf{n}^{-1}\right)$ & $1.32 \mathrm{E}-13$ \\
\hline$\Phi_{\mathrm{th}} / \Phi_{\mathrm{epi}}$ & 0.008 \\
\hline $\mathbf{J} / \Phi_{\text {total }}$ & 0.73 \\
\hline
\end{tabular}

From the table above, the epithermal flux intensity has not fulfill IAEA's design recruitment. Thus for this research the optimization is focusing at moderator component. Beside for in vivo and in vitro trials purposes, the aperture's radius beam hole have to resize to wider radius.

\section{RESULTS AND DISCUSSION}

\section{Reactor criticality}

The criticality calculation by using MCNPX gave result $1.01186 \pm 0.000$ wich was a good approach to the actual reactor criticality value of $1.000+0.010$.

\section{Optimization of collimator}

Former collimator design were optimizing in order to produce an ideal beam for BNCT procedure to fulfil IAEA's recruitment. Optimization was doing so that the beam output meets the standard criteria of the IAEA, the aim of optimization because of previous results have not fulfilled all the criteria of the IAEA, namely epithermal flux, epithermal flux generated only $7.57 \mathrm{E}+08$ n.cm-2.s-1, while the other parameters have meet, for this research, optimization is focused on increasing the epithermal flux, efforts are made to find material and optimum thickness variation for the moderator, of course, the expected results will meet IAEA standards

\section{Collimator Wall}

Based on the research that has been done before, the best material for collimator wall is nickel, because nickel has an atomic number that is not too small, and could result in a decrease in neutron flux, but the decline was not too large, and is also able to raise a little neutron energy spectrum, in fact natural nickel was able to produce epithermal neutrons without moderator, but to improve the quality of light is better then the moderator is still required.

\section{Moderator}

Materials simulated for material candidates for moderator are $\mathrm{TiF} 3, \mathrm{MgF} 2, \mathrm{~S}$, and A1. 
Ranti Warfi, Andang Widi Harto, Yohannes Sardjono, Widarto, Optimization of Neutron Collimator in The Thermal Column of Kartini Research Reactor for in vitro and in vivo Trials Facility of Boron Neutron Capture Therapy using MCNP-X Simulator

Table 3. Result of Beam Parameter For Various Thickness of Moderator (S)

\begin{tabular}{|c|c|c|c|c|c|c|c|}
\hline \multirow{2}{*}{\multicolumn{2}{|c|}{$\frac{\text { Moderator }}{\text { Sulfur }}$}} & \multirow{2}{*}{\multicolumn{2}{|c|}{$\begin{array}{c}\text { Filter Neutron } \\
\text { Nikel }\end{array}$}} & \multirow{2}{*}{\multicolumn{3}{|c|}{$\begin{array}{c}\text { Filter Gamma } \\
\text { Bismuth }\end{array}$}} & \multirow[b]{3}{*}{$\mathbf{J} / \boldsymbol{\Phi}_{\text {total }}$} \\
\hline & & & & & & & \\
\hline $\begin{array}{l}\text { Thickness } \\
\text { (cm) }\end{array}$ & $\frac{\Phi_{\text {epi }}}{\text { (n.cm-2.s-1) }}$ & $\begin{array}{c}\text { Thickness } \\
\text { (cm) }\end{array}$ & $\begin{array}{c}\text { Ďf/ } / \Phi_{\mathrm{epi}} \\
\left(G y \cdot \mathrm{cm}^{2} \cdot \mathbf{n}^{-1}\right)\end{array}$ & $\begin{array}{c}\text { Thickness } \\
(\mathrm{cm})\end{array}$ & $\begin{array}{c}\check{D} \gamma / \Phi_{\mathrm{epi}} \\
\left(G y \cdot \mathrm{cm}^{2} \cdot \mathbf{n}^{-1}\right)\end{array}$ & $\boldsymbol{\Phi}_{\mathrm{th}} / \boldsymbol{\Phi}_{\mathrm{epi}}$ & \\
\hline 5 & $2.20 \mathrm{E}+09$ & 15 & $2.94 \mathrm{E}-13$ & 3 & $2.65 \mathrm{E}-13$ & $2.86 \mathrm{E}-02$ & $7.13 \mathrm{E}-01$ \\
\hline 10 & $2.12 \mathrm{E}+09$ & 15 & $2.77 \mathrm{E}-13$ & 3 & $3.04 \mathrm{E}-13$ & $3.05 \mathrm{E}-02$ & 7.19E-01 \\
\hline 15 & $1.87 \mathrm{E}+09$ & 15 & $2.77 \mathrm{E}-13$ & 3 & $2.65 \mathrm{E}-13$ & $2.54 \mathrm{E}-02$ & $7.15 \mathrm{E}-01$ \\
\hline 20 & $1.62 \mathrm{E}+09$ & 15 & $2.53 \mathrm{E}-13$ & 3 & $2.74 \mathrm{E}-13$ & $2.54 \mathrm{E}-02$ & $7.46 \mathrm{E}-01$ \\
\hline 25 & $1.63 \mathrm{E}+09$ & 15 & $2.00 \mathrm{E}-13$ & 3 & $2.05 \mathrm{E}-13$ & $2.74 \mathrm{E}-02$ & 7.14E-01 \\
\hline 30 & $1.31 \mathrm{E}+09$ & 15 & $1.91 \mathrm{E}-13$ & 3 & $1.77 \mathrm{E}-13$ & $1.61 \mathrm{E}-02$ & $7.04 \mathrm{E}-01$ \\
\hline
\end{tabular}

Table 4. Result of Beam Parameter for Various Thickness of Neutron Filter(Ni)

\begin{tabular}{|c|c|c|c|c|c|}
\hline Filter (cm) & $\begin{array}{c}\Phi_{\text {epi }} \\
\text { (n.cm-2.s-1) }\end{array}$ & $\begin{array}{c}\text { Ďf/ } / \Phi_{\mathrm{epi}} \\
\left(G y \cdot \mathrm{cm}^{2} \cdot \mathrm{n}^{-1}\right)\end{array}$ & $\begin{array}{c}\text { Ď } \gamma / \Phi_{\text {epi }} \\
\left(G y \cdot \mathrm{cm}^{2} \cdot n^{-1}\right)\end{array}$ & $\boldsymbol{\Phi}_{\mathrm{th}} / \boldsymbol{\Phi}_{\mathrm{epi}}$ & $\mathbf{J} / \boldsymbol{\Phi}_{\text {total }}$ \\
\hline 20 & $1.27 \mathrm{E}+09$ & $1.46 \mathrm{E}-13$ & $2.05 \mathrm{E}-13$ & $6.69 \mathrm{E}-03$ & $7.47 \mathrm{E}-01$ \\
\hline 25 & $1.11 \mathrm{E}+09$ & $1.40 \mathrm{E}-13$ & $1.24 \mathrm{E}-13$ & $5.85 \mathrm{E}-03$ & $7.16 \mathrm{E}-01$ \\
\hline 30 & $1.01 \mathrm{E}+09$ & $1.06 \mathrm{E}-13$ & $1.30 \mathrm{E}-13$ & $5.55 \mathrm{E}-03$ & 7.07E-01 \\
\hline
\end{tabular}

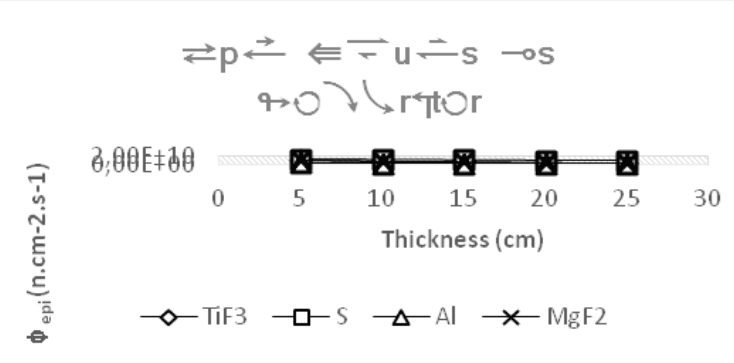

Figure 5. Epithermal Flux for Various Moderator Materials and Thickness

From the graph in Figure 4 could be concluded that for the result of moderator, sulfur is much better than other materials, and also in terms of economy aspect, sulfur also certainly cheaper than TiF3 and MgF2.

\section{Neutron Filter}

In this study, the thickness of reference for thermal and fast neutron filter is Nickel with a thickness of $15 \mathrm{~cm}$, based on previous research. At the previous study, this material proven to reduce thermal and fast neutrons, and improve the beam quality of epithermal neutron.

This happens because nickel has a minimum cross section in the range of epithermal neutrons, can be seen from the following picture;

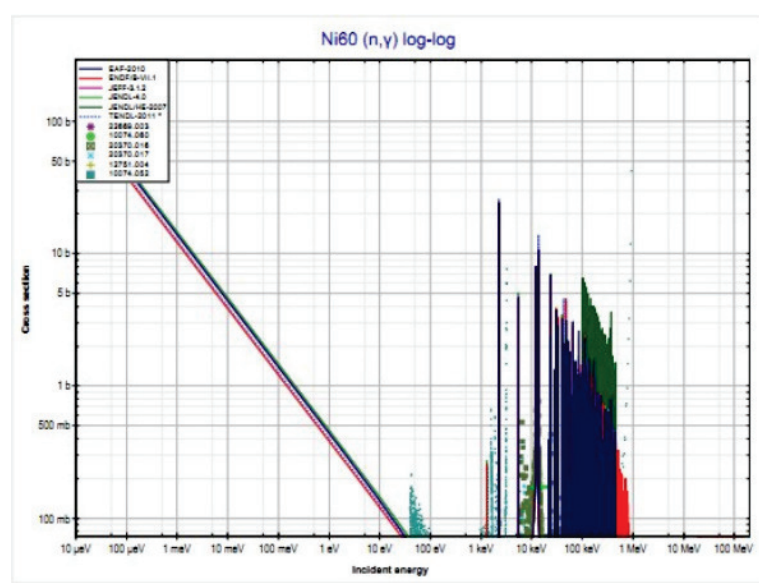

Figure 6. Neutron Cross-section for ${ }^{60} \mathrm{Ni}$ (N. Soppera, 2012)

After the simulation is done with sulfur material that has a thickness of $30 \mathrm{~cm}$ and filter thermal and fast neutrons can be seen fast neutron dose of 1.91E-13 Gy.cm2.n-1, although the fast neutron dose is below the parameter of the IAEA, but the value is very close to IAEA threshold parameter, while for the gamma dose was far from the threshold parameters of the IAEA, in order to obtain optimal results it is necessary optimization of the thickness of the filter.

Based on the results, optimization of the thickness of the filter in table IV, could be seen 
in terms of flux of epithermal and quality $\mathrm{j}$ thickness, filter most optimum is at a thickness of $20 \mathrm{~cm}$, in terms of dose fast neutrons and gamma rays best results are at a thickness of $30 \mathrm{~cm}$, but if considered at a thickness of 20 $\mathrm{cm}$ dose fast neutrons and gamma rays have also been very good and far from the threshold parameter of IAEA.

\section{Gamma Shielding}

Based on previous research showed that the material that is the most optimal in reducing the rate of dose gamma is $\mathrm{Bi}$ with a thickness of $2 \mathrm{~cm}$, the performance of Bi evidenced by the results of the simulation in this study at the table when the radius of the aperture is enlarged to $8 \mathrm{~cm}$, dose gamma still far below IAEA's maximum dose

\section{Aperture for in vivo and in vitro trials}

As collimator is for in vivo and in vitro trials purpose, the aperture is designed as wide as possible with the aim be used for large-scale irradiation. From Table V it can be seen that all the parameters of the IAEA at the time aperture of radius $8 \mathrm{~cm}$, while the other measures the value of J / $\Phi$ total is still below the standards of the IAEA.

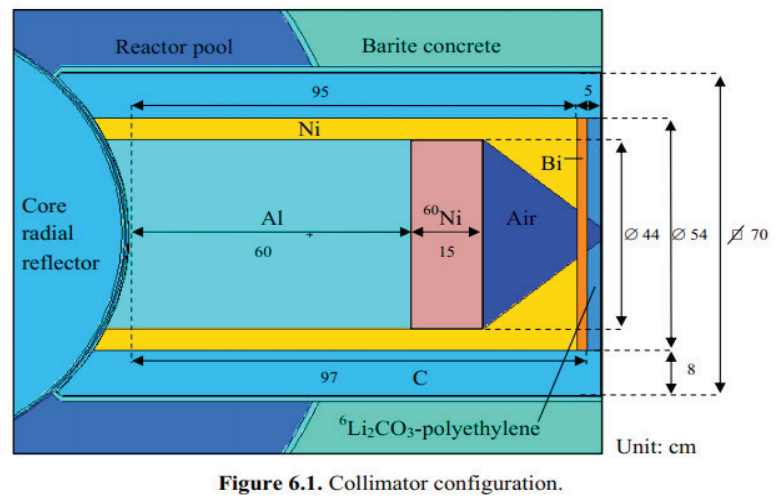

Figure 7. Collimator Configuration Before Optimization (Nina Fauziah, 2013)

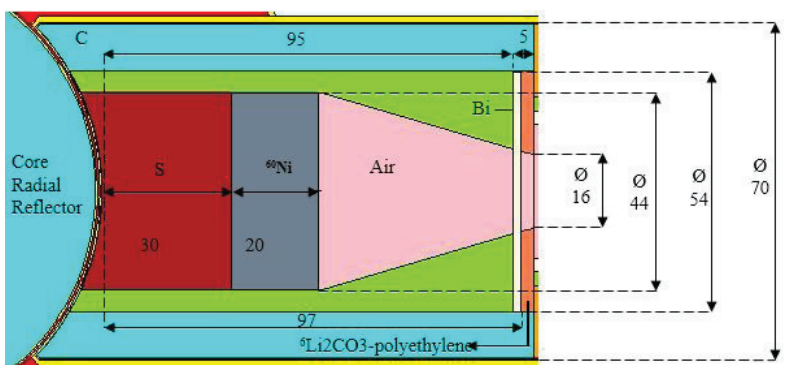

Figure 8. Collimator Configuration Optimized

\section{CONCLUSION AND REMARKS}

Based on the research that has been done, the result is optimal for collimator design of Kartini reactor in thermal column as follows,

Optimization of collimator for in vivo and in vitro trials configuration are as follows, 1. Ni $5 \mathrm{~cm}$ of thickness as collimator wall. 2. $\mathrm{S} 30 \mathrm{~cm}$ of thickness as moderator 2 .

Table 5. Result of Beam Parameter for Different Aperture Radius

\begin{tabular}{cccccc}
\hline $\begin{array}{c}\text { aperture } \\
(\mathrm{R}=\mathrm{cm})\end{array}$ & $\begin{array}{c}\boldsymbol{\Phi}_{\text {epi }} \\
(\mathrm{n} . \mathrm{cm}-2 . \mathrm{s}-1)\end{array}$ & $\begin{array}{c}\check{\mathbf{D}} / \boldsymbol{\Phi}_{\text {epi }} \\
\left(\mathrm{Gy} \cdot \mathrm{cm}^{2} \cdot \mathrm{n}^{-1}\right)\end{array}$ & $\begin{array}{c}\check{\mathbf{D}} \gamma / \boldsymbol{\Phi}_{\text {epi }} \\
\left(\mathrm{Gy} \cdot \mathrm{cm}^{2} . \mathrm{n}^{-1}\right)\end{array}$ & $\boldsymbol{\Phi}_{\text {th }} / \boldsymbol{\Phi}_{\text {epi }}$ & $\mathrm{J} / \boldsymbol{\Phi}_{\text {total }}$ \\
\hline 15 & $1.34 \mathrm{E}+09$ & $1.67 \mathrm{E}-13$ & $1.28 \mathrm{E}-13$ & $9.08 \mathrm{E}-03$ & $6.36 \mathrm{E}-01$ \\
14 & $1.30 \mathrm{E}+09$ & $1.87 \mathrm{E}-13$ & $1.36 \mathrm{E}-13$ & $1.11 \mathrm{E}-02$ & $6.47 \mathrm{E}-01$ \\
13 & $1.26 \mathrm{E}+09$ & $1.68 \mathrm{E}-13$ & $2.55 \mathrm{E}-13$ & $8.27 \mathrm{E}-03$ & $6.52 \mathrm{E}-01$ \\
12 & $1.22 \mathrm{E}+09$ & $1.69 \mathrm{E}-13$ & $1.49 \mathrm{E}-13$ & $9.16 \mathrm{E}-03$ & $6.67 \mathrm{E}-01$ \\
11 & $1.21 \mathrm{E}+09$ & $1.70 \mathrm{E}-13$ & $1.50 \mathrm{E}-13$ & $8.85 \mathrm{E}-03$ & $6.75 \mathrm{E}-01$ \\
10 & $1.17 \mathrm{E}+09$ & $1.70 \mathrm{E}-13$ & $1.56 \mathrm{E}-13$ & $9.40 \mathrm{E}-03$ & $6.84 \mathrm{E}-01$ \\
9 & $1.16 \mathrm{E}+09$ & $1.79 \mathrm{E}-13$ & $1.64 \mathrm{E}-13$ & $9.75 \mathrm{E}-03$ & $6.87 \mathrm{E}-01$ \\
8 & $1.13 \mathrm{E}+09$ & $1.76 \mathrm{E}-13$ & $1.45 \mathrm{E}-13$ & $1.08 \mathrm{E}-02$ & $7.05 \mathrm{E}-01$ \\
7 & $1.10 \mathrm{E}+09$ & $1.73 \mathrm{E}-13$ & $1.45 \mathrm{E}-13$ & $1.05 \mathrm{E}-02$ & $7.10 \mathrm{E}-01$ \\
6 & $1.05 \mathrm{E}+00$ & $1.69 \mathrm{E}-13$ & $1.40 \mathrm{E}-13$ & $1.03 \mathrm{E}-02$ & $7.17 \mathrm{E}-01$ \\
\hline
\end{tabular}


Table 6. Comparison of Beam Parameter After and Before Optimization of Colimator Design

\begin{tabular}{cccc}
\hline Mnemonic & Before Optimization & Optimized & Design Recruitment (IAEA) \\
\hline$\Phi_{\text {epi }}(\mathrm{n} . \mathrm{cm}-2 . \mathrm{s}-1)$ & $7.57 \mathrm{E}+08$ & $1.13 \mathrm{E}+09$ & $>1.0 \mathrm{E}+09$ \\
$\mathrm{D} \mathrm{f} / \Phi_{\text {epi }}\left(\mathrm{Gy} \cdot \mathrm{cm}^{2} \cdot \mathrm{n}^{-1}\right)$ & $1.81 \mathrm{E}-13$ & $1.76 \mathrm{E}-13$ & $<2.0 \mathrm{E}-13$ \\
$\check{\mathrm{D}} \gamma / \Phi_{\text {epi }}\left(\mathrm{Gy} \cdot \mathrm{cm}^{2} \cdot \mathrm{n}^{-1}\right)$ & $1.32 \mathrm{E}-13$ & $1.45 \mathrm{E}-13$ & $<2.0 \mathrm{E}-13$ \\
$\Phi_{\text {th }} / \Phi_{\text {epi }}$ & 0.008 & 0.0108 & $<0.05$ \\
$\mathrm{~J} / \Phi_{\text {total }}$ & 0.73 & 0.705 & $>0.7$ \\
\hline
\end{tabular}

3. ${ }^{60} \mathrm{Ni} 20 \mathrm{~cm}$ of thickness thermal neutron filter.

4. Bi $2 \mathrm{~cm}$ of thickness as gamma shielding and $6 \mathrm{Li} 2 \mathrm{CO} 3$ polyethylene $3 \mathrm{~cm}$ of thickness.

This study concluded that the optimized collimators design feasible for use in BNCT facility Kartini reactor to in vivo and in vitro trial because,

First, the output beam meets all the criteria of the IAEA.

Second, the radius of the aperture after optimization design allows for in vivo and in vitro trials facility compared to the previous design.

\section{ACKNOWLEDGMENT}

The author wish to thank Dr. Ir. Andang Widi Harto, Prof. Ir. Yohannes Sardjono and Drs. Widarto for any instructions and guidances to complete this research .

I would to thank Head of PSTA-BATAN Babarsari Dr. Susilo Widodo who has allowed to conduct the research in PSTA-BATAN.

The author also appreciates colleagues who have been together with the author conducted this research.

\section{POLICY BRIEF}

Based on data from Buletin kanker Indonesian health ministry department, 70\% of all cancer treatment used radiotherapy, on the other hand number of radiotherapy equipments in Indonesia is quite low despite of the cancer patients. BNCT as new cancer treatment research in Indonesia is a new hope to increase patient's lifespan. The development level of BNCT research in Indonesia is in simulation level, but the simulation has shown good results. I hope Indonesian government support this research until it can be applied for clinical uses.

\section{REFERENCES}

Abdi, M. (2012). Collimator Design for Neutron Radiography Systems Using a Reactor Flux. Middle-East Journal of Scientific Research , 11(ISSN 1990-9233), 648-651.

Fatemeh S. Rasouli, S. F. (2012). Design and optimiz ation of a beam shaping assembly for BNCT based on D-T neutron generator and dose evaluation using a simulated head phantom. Applied Radiation and Isotopes, $1-2$.

Fatemeh s.Rasouli, S. M. (2011). Design of a model for BSA to meet free bam parameter for BNCT on multiplier system for D-T neutron source. Annals of Nuclear Energy, $1-2$.

IAEA. (2001). Current status of neutron capture therapy. Vienna: Applied Radiation Biology and Radiation Dosimetry dan Medical Radiation Physics Section Division of Human Health and Physics Section Division of Physical and Chemical Science.

K W Burn, L. C. (2006). The epithermal neutron beam for BNCT under construction at TAPIRO :Physics. EPS Euroconfrence XIX Nuclear Physics Divisional Confrence, 1-3. 
Lucas, G. (2010). MCNP Tutorial. Wincousin: UW-Engineering Physics Department.

M.Ilma Muslih Arrozaqi. (2014). Dasar-Dasar Pemrograman MCNPX. Yogyakarta: Pusat Sains dan Teknologi Akselerator Badan Tenaga Nuklir Nasional.

MacGillivray, G. (2011). Neutron Radiography Collimator Design. Petawawa, Ontario, Canada: Nray Services Inc.

N. Soppera, E. D. (2012). JANIS Book of neutron-induced cross-sections. Issy-lesMoulineaux: AEN-NEA.

Nakagawa, W. A. (2012). Neutron Capture therapy: principles and aplication . London: Springer.

Nina Fauziah. (2013). A Conceptual Design of Neutron Collimator in The Thermal Column of Kartini Research Reactor for Boron Neutron Capture Therapy. Yogyakarta, Indonesia: Departemen Teknik Fisika, Fakultas Teknik, Universitas Gadjah Mada.

Organization, W. H. (2012, Agustus). Internation Agency of Research on Cancer. Retrieved Agusutus 25, 2015, from Internation Agency of Research on Cancer: http://www.iarc.fr/ en/media-centre/iarcnews/pdf/Global $\% 20$ factsheet-2012.pdf

RI, D. K. (2015, Februari 4). Departemen Kementrian Kesehatan RI. Retrieved
Agustus 25, 2015, from website Departemen Kementrian Kesehatan RI: http://www. depkes.go.id/resources/download/pusdatin/ buletin/buletin-kanker.pdf

SEPPÄLÄ, T. (2002). FIR 1 EPITHERMAL NEUTRON BEAM MODEL. Helsinki: Department of Physical Sciences Faculty of Science University of Helsinki.

Sofia Mubarika, M. M. (2006). Analisis dan Penentuan Distribusi Fluks Neutron Thermal Arah Aksial dan Radial Teras Reaktor Kartini dengan Detektor Swadaya. Jurnal Sains \& Matematika (JSM), 14(4), 155-159.

Tribe, T. N. (n.d.). News Tribe. Retrieved SEPTEMBER 2015, 7, from www. thenewstribe.com

Turkoglu, D. j. (2012). Design, Construction and Characterization of an External Neutron Beam Facility at The Ohio State University Nuclear Reactor Laboratory. Ohio: Ohio State University .

W. A. G. Sauerwein, A. Wittig, R. Moss, \& Y. Nakagawa. (2012). Neutron Capture Therapy: Principles and Application. Berlin: SpringerVerlag.

World Health Organization. (2015, Februari). Cancer. Retrieved Juli 13, 2015, from http:// www.who.int/mediacentre/factsheets/fs297/ en/ 